\title{
SPORT I ZDRAVLJE U REPUBLICI SLOVENIJI U 2009. GODINI
}

\author{
Ivan Čuk ${ }^{1}$, Maja Bučar Pajek ${ }^{1}$ Jernej Pajek $^{2}$ i Mojca Peček ${ }^{3}$
}

${ }^{1}$ Fakultet sporta, Univerzitet Ljubljana, Slovenija

${ }^{2}$ Medicinski fakultet, Univerzitet Ljubljana, Slovenija

${ }^{3}$ Pedagoški fakultet, Univerzitet Ljubljana, Slovenija

doi: 10.5550/sgia.110702.se.121C

ORGINALNI NAUČNI ČLANAK

COBISS.BH-ID: 2428184

UDK: 796+614(497.4)"2009"

\section{SAŽETAK}

Sport i zdravlje se često smatraju povezanim. Olimpijski komitet Slovenije, Odeljenje Sport za sve, željelo je da utvrdi da li je broj ljudi uključenih u organizovane sportske aktivnosti u regionu u korelaciji sa stepenom pojave različitih oblika bolesti. Opštinske vlasti obezbijedile su informacije o broju klubova i broju njihovih članova u 2009. godini. Statistički godišnjak iz 2009. godine Statističkog zavoda Republike Slovenije obezbijedio je demografske informacije u opštinama za 2009. godinu. Agencija za finansije dostavila je podatke o finansiranju sporta u opštinama Slovenije u 2009. godini. Institut za javno zdravstvo (Zdravstveni statistički godišnjak 2009) dao je pregled tretmana određenih bolesti u početnoj fazi koje su dijagnostifikovane u skladu sa međunarodnom MKB-10 klasifikacijom. Rezultati su pokazali da organizovani sport zaista smanjuje nivo određenih zdravstvenih problema (kao npr. respiratornih). Odnos javnih sredstava po članu sportskog društva je u korelaciji sa pojavom digestivnih bolesti, simptoma i abnormalnih kliničkih i laboratorijskih nalaza koja nisu nigdje drugo klasifikovana. Veće plate zaposlenih u tim klubovima takođe utiču na pojavu respiratornih bolesti, bolesti koštano - mišićnog aparata, gastrointestinalnih bolesti, kao i povreda i trovanja pod uticajem spoljašnjih faktora. Ovi rezultati podupiru činjenicu da sportski klubovi nekada djeluju kao prirodne apoteke. Povećano ulaganje sredstava u sportske klubove vjerovatno bi dovelo do poboljšanja zdravlja cijele nacije i sačuvalo resurse koji se sada koriste za liječenje.

Ključne riječi: sportski klubovi, finansije, dijagnoza.

\section{UVOD}

Zdravlje, prema definiciji SZO (World Helth Organization, 1986), predstavlja »resurs za svakodnevni život, a ne cilj života, zdravlje je pozitivan koncept koji naglašava socijalne i lične resurse, kao i fizičke sposobnosti«. Evropska sportska povelja (Concile of Europe, 1992) definiše »sport« kao sredstvo svih oblika fizičke aktivnosti koje kroz spontano ili organizovano učešće, imaju za cilj da izraze ili poboljšaju kondiciju i mentalno blagostanje ostvarivanjem društvene povezanosti, ili održanjem rezultata na svim nivoima takmičenja. Iz obje definicije može se zaključiti da su sport i zdravlje povezani.

Postoji dugačak spisak studija koje su dokazale da sportska aktivnost ima pozitivan efekat na poboljšanje zdravstvenog stanja; a mi ćemo se baviti onima koje ispituju kako fizičke aktivnosti poboljšavaju zdravlje na generalnom i specifičnom nivou. Karaca- bey (2005) je napisao da fizičko vježbanje utiče na zdravlje i ima značajnu preventivnu ulogu za nekoliko različitih bolesti; podiže radnu sposobnost, što bi trebalo imati pozitivan uticaj na nacionalnu ekonomiju i kvalitet života. Viru i Smirnova (1995) tvrde da su vježbe izdržljivosti najvažnije za poboljšanje zdravlja. Gimnastičke vježbe su neophodne kada se pominje mehanički antisklerotički efekat i centralni nervni sistem. Prema Tanaka (2009), plivanje može poboljšati kardiovaskularno zdravlje, a prema Almeida i saradnici (2009), plivanje usporava razvoj tumora. Prema tvrdnjama Sattelmair, Kurth, Buring i Lee (2010), žene koje su fizički aktivne imaju manji rizik od pojave moždanog udara. Sa fizičkom aktivnošću i pravilnim načinom ishrane možemo umanjiti gojaznost, kao i rizik od povreda (Finkelstein, Chen, Prabhu, Trogdon i Corso, 2007; Gram, Cristensen, Christiansen i Gram 2010; Miculis, Mascarenhas, Boguszewski i de Campos, 2010; Snyder i saradnici, 
2010). Kano (1998), Nichols, Sanborn i Essery (2007) i Roger i Hinton (2010) dokazali su da fizička aktivnost olakšava mineralizaciju koštanog sistema. Fizička aktivnost pospješuje ili koristi onima koji pate od depresije (Stammes i Spijker, 2009) ili astme (Juvonen i saradnici, 2008; Weisberg i saradnici, 2009), i stimuliše gastrointestinalni sistem (de Oliviera i Burini, 2009). Kao što je tvrdio Vuori (2004), fizička neaktivnost je uzrok velikih javnih zdravstvenih problema, dok je fizička aktivnost lijek za njih.

Sa druge strane, takođe je dobro poznato da neke sportske aktivnosti (pretjerano vježbanje) takođe mogu oštetiti zdravlje. Preopterećenje, povrede, sudari pa čak i smrt su faktori rizika koji se javljaju u sportu (Boughlat, Turmel, Levesque i Boulet, 2009; Bučar Pajek i Pajek, 2009; Dowdel, 2011; Emery i Tyreman, 2009; Mafuli, Longo, Spiezia i Denaro, 2010; Redelmeier i Greenwald, 2007).

$\mathrm{Na}$ nacionalnom (državnom) nivou postoje samo retke informacije o tome kako sport utiče na nacionalno zdravlje. Oven, Bauman, Braun i Trost (2003) raspravljaju o ovoj temi u svom članku Fizicicka aktivnost i ishodi pozitivne i negativne strane sporta i fizicke aktivnosti na zdravlje stanovnika, i slažu se da treba potencirati fizičku aktivnost (umjerenu), jer ima mnogo pozitivnih rezultata, ali ne navode konkretne podataka o tome. Zheng, Ehrlich i Amin (2010) uradili su ekonomsku procjenu direktne novčane uštede do koje bi se došlo korištenjem šetnje u prevenciji srčanih bolesti u Australiji, i navode da bi ušteda bila ogromna. Veoma interesantno istraživanje objavljeno je od strane Lambert i saradnici (2009). Analizirali su obim fizičke aktivnosti članova najvećeg Južnoafričkog privatnog zdravstvenog osiguranja $(n=948.974)$ i zahtijeva za bolničkim tretmanom aktivnih i neaktivnih grupa poslije usklađivanja u dobi, polu, medicinskom planu i koristi od hroničnih bolesti; troškovi bolničkog lečenja po osobi bili su niži za svaku aktivnu grupu u odnosu na neaktivne. Powell, Salter, Chalupka i Harper (2006) došli su do zaključka da nedostatak objekata koji obezbeđuju i promovišu fizičku aktivnost mogu, u određenom stepenu, da podstaknu smanjenje fizičke aktivnosti posmatrane među populacijom nižeg socijalno-ekonomskog statusa.

Dok fizička aktivnost i sport imaju uticaja na ljudsko zdravlje (pozitivan i negativan), i pored pretrage nekoliko baza podataka (Web of Science, PUBMED) nismo dobili podatke o tome kako su sportske aktivnosti i broj sportski aktivnih ljudi povezani sa nacionalnim zdravljem bilo koje države. Ima mnogo razloga zbog kojih ne postoje takvi podaci. Vjerovatno najvažniji među njima jeste taj što vlade ne čuvaju podatke o broju ljudi uključenih u sport, i drugi razlog jeste nedostatak zdravstvene statistike.

Slovenija je mala država u središtu Evrope koja se na sjeveru graniči sa Austrijom, na zapadu sa Italijom, na istoku Mađarskom i na jugu sa Hrvatskom. U 2009. godini, imala je 2.032.362 stanovnika. U 2000. godini, Olimpijski komitet Slovenije - Udruženje sportskih saveza i njihovo odjeljenje Sport za sve, pokrenuli su akciju pod nazivom »Sport, recept za zdravlje«, sa ciljem da oko 6.000 sportskih klubova u Sloveniji doprinesu poboljšanju nacionalnog zdravlja, promovišući ideju da sportski klub može poslužiti kao prirodna apoteka. U tom trenutku Vlada Slovenije nije prihvatila argument da sportski klubovi mogu služiti kao prirodne apoteke i poboljšati zdravlje, jer su negativne posljedice vrhunskog sporta bile neosporne (poražavajuće). U Sloveniji zdravstvena statistika je u nadležnosti Instituta za javno zdravstvo Republike Slovenije (Inštitut za varovanje zdravja - IVZ), koji objavljuje Godišnjak zdravstvene statistike. Demografska i ekonomska statistika su u nadležnosti Zavoda za statistiku Republike Slovenije koji objavljuje Statističke godišnjake. Agencija Republike Slovenije za javne pravne evidencije i srodne službe, obezbijedila je podatke o sredstvima potrošenim na organizovani sport na teritoriji Slovenije u 2009. godini. Niko u Sloveniji nije odgovoran za sportsku statistiku. Iz tog razloga, dobili smo sopstvene podatke o broju aktivnih članova sportskih klubova u Sloveniji.

Koristeći sumirane podatke iz različitih regija, željeli smo da istražimo: da li je odnos organizovanih sportski aktivnih članova u vezi sa zdravstvenim statusom definisanim MKB-10; da li je količina javnih sredstava po sportski aktivnom članu u vezi sa zdravstvenim statusom MKB-10, i da li je visina plata zaposlenih u vezi sa zdravstvenim statusom MKB-10.

\section{METODE}

Slovenija je podijeljena u 12 statističkih regija: Pomurska, Podravska, Koroška, Savinjska, Gorenjska, Zasavska, Osrednja, Spodnje posavska, Jugovzhodna, Gorška, Obalno-kraška i Notranjsko-kraška. Ove regije činile su naš uzorak $(N=12)$. Godišnjak zdravstvene statistike, iz 2009. Godine, dao nam je podatke o razlozima za posjetu ambulantnim zdravstvenim ustanovama na primarnom nivou, kako je definisano poglavljima MKB-10. MKB-10 kategorizuje dijagnoze na sljedeći način:

- I - Infekcijske i parazitne bolesti;

- II - Neoplazme;

- III - Bolesti krvi i krvnotvornih organa i određeni poremećaji u vezi sa imunim sistemom; 
- IV - Endokrine, nutritivne i metaboličke bolesti;

- V - Mentalni poremećaji i poremećaji ponašanja; TABELA 1

Demografske i sportske karakteristike regija

\begin{tabular}{lrrrrrc}
\hline \multicolumn{1}{c}{ Regija } & 1 & \multicolumn{1}{c}{2} & \multicolumn{1}{c}{3} & \multicolumn{1}{c}{4} & \multicolumn{1}{c}{5} & 6 \\
\hline Pomurska & 119537 & 313 & 18813 & 157.38 & 73.18 & 784.68 \\
\hline Podravska & 322900 & 617 & 72841 & 225.58 & 85.14 & 933.09 \\
\hline Koroška & 72481 & 218 & 12783 & 176.36 & 176.36 & 806.23 \\
\hline Savinjska & 258845 & 566 & 50148 & 193.74 & 193.74 & 813.35 \\
\hline Zasavska & 44750 & 125 & 7453 & 166.55 & 166.55 & 851.85 \\
\hline Spodnjeposavska & 69900 & 166 & 9030 & 129.18 & 129.18 & 838.46 \\
\hline Jogovzhodna & 141166 & 213 & 17910 & 126.87 & 126.87 & 839.75 \\
\hline Osrednjeslovenska & 521965 & 912 & 87204 & 167.07 & 167.07 & 938.29 \\
\hline Gorenjska & 201779 & 634 & 41450 & 205.42 & 205.42 & 868.03 \\
\hline Notranjsko-Kraška & 51728 & 122 & 6059 & 117.13 & 117.13 & 806.12 \\
\hline Goriška & 118533 & 389 & 22275 & 187.92 & 187.92 & 876.74 \\
\hline Obalno-Kraška & 108778 & 193 & 21508 & 197.29 & 197.29 & 893.69 \\
\hline$\Sigma$ & 2032362 & 4468 & 367474 & Average & 113.64 & \\
\hline
\end{tabular}

Legenda: 1 - Broj stanovnika; 2 - Broj sportskih klubova; 3 - Broj članova sportskih klubova;

4 - Broj članova / 1.000 stanovnika; 5 - Godišnja javna potrošnja po članu sportskog kluba

(EUR); 6 - Prosječna mjesečna neto plata po zaposlenom (EUR); $\boldsymbol{\Sigma}$ - Ukupno.

- VI - Bolesti nervnog sistema;

- VII - Bolesti oka i adnexa;

- VIII - Bolesti uha i mastoidnih procesa;

- IX - Bolesti sistema za cirkulaciju;

- X - Bolesti respiratornog sistema;

- XI - Bolesti probavnog sistema;

- XII - Bolesti kože i potkožnog tkiva;

- XIII - Bolesti mišićno koštanog sistema i vezivnog tkiva;

- XIV - Bolesti genitalno urinarnog sistema;

- XV - Trudnoća i porođaj;

- XVI - Određena stanja porođajnog perioda;

- XVII - Urođene malformacije, deformacije i hromozomske abnormalnosti;

- XVIII - Simptomi, znakovi i abnormalni klinički i laboratorijski nalazi, koji nisu klasifikovani;

- XIX - Povrede, trovanja i određene druge posledice s spoljašnjim uzrokom.

Statistički Godišnjak 2009. prezentovao je podatke o broju stanovnika po regijama i o prosječnom primanju zaposlenih osoba. Agencija Republike Slovenije za javne pravne evidencije i srodne službe obezbijedila je podatke o javnom finansiranju, usmjerenom na organizovani sport po regijama u 2009. godini. Koristeći metode upitnika i intervjua, pitali smo sve opštinske vlasti u Sloveniji koliko je sportskih klubova u njihovoj opštini finansirano iz opštinskog budžeta i koliko su članova imali u 2009. godini (in- tervjui su sprovedeni u aprilu i maju 2010. godine). Od 210 opština, 207 je odgovorilo (99\% posto odgovora koji su praktično cijelo stanovništvo opština). Opštinski podaci su potom uključeni u regionalne. Nakon toga, svi podaci su normalizovani u 1000 stanovnika po regionu. Statistička analiza rađena je u programu SPSS 17.0. Izračunata je deskriptivna statistika i Pirsonov koeficijent korelacije. Pirsonov koeficijent je značajan na nivou $p<0,05$ kada je vrijednost korelacionog koeficijenta veća od 0,506.

\section{REZULTATI}

Slovenačke regije imaju prilično različite osnovne demografske i sportske karakteristike (Tabela 1). Neke se odnose na razloge prisustva na primarnom nivou (Tabela 2). Samo nekoliko korelacija među demografskim, sportskim varijablama i razlozima za posjetu ambulantnim zdravstvenim ustanovama na primarnom nivou bili su statistički značajni (Tabela 3).

\section{DISKUSIJA}

Naši rezultati (Tabela 1) pokazuju malo drugačiju sliku od one koju su dobila neka prethodna istraživanja. Najveća razlika je u broju sportskih klubova i u broju onih koje finansiraju opštine (4.468 opštinski-finansiranih klubova u odnosu na 6.115 zvaničnih sportskih klubova (Kolar, Jurak i Kovač, 2010). U 
TABELA 2

Regionalni razlozi za posetu ambulantnim zdravstvenim ustanovama

na primarnom nivou po poglavliima $M K B$ - 10 (na 1000 stanovnika)

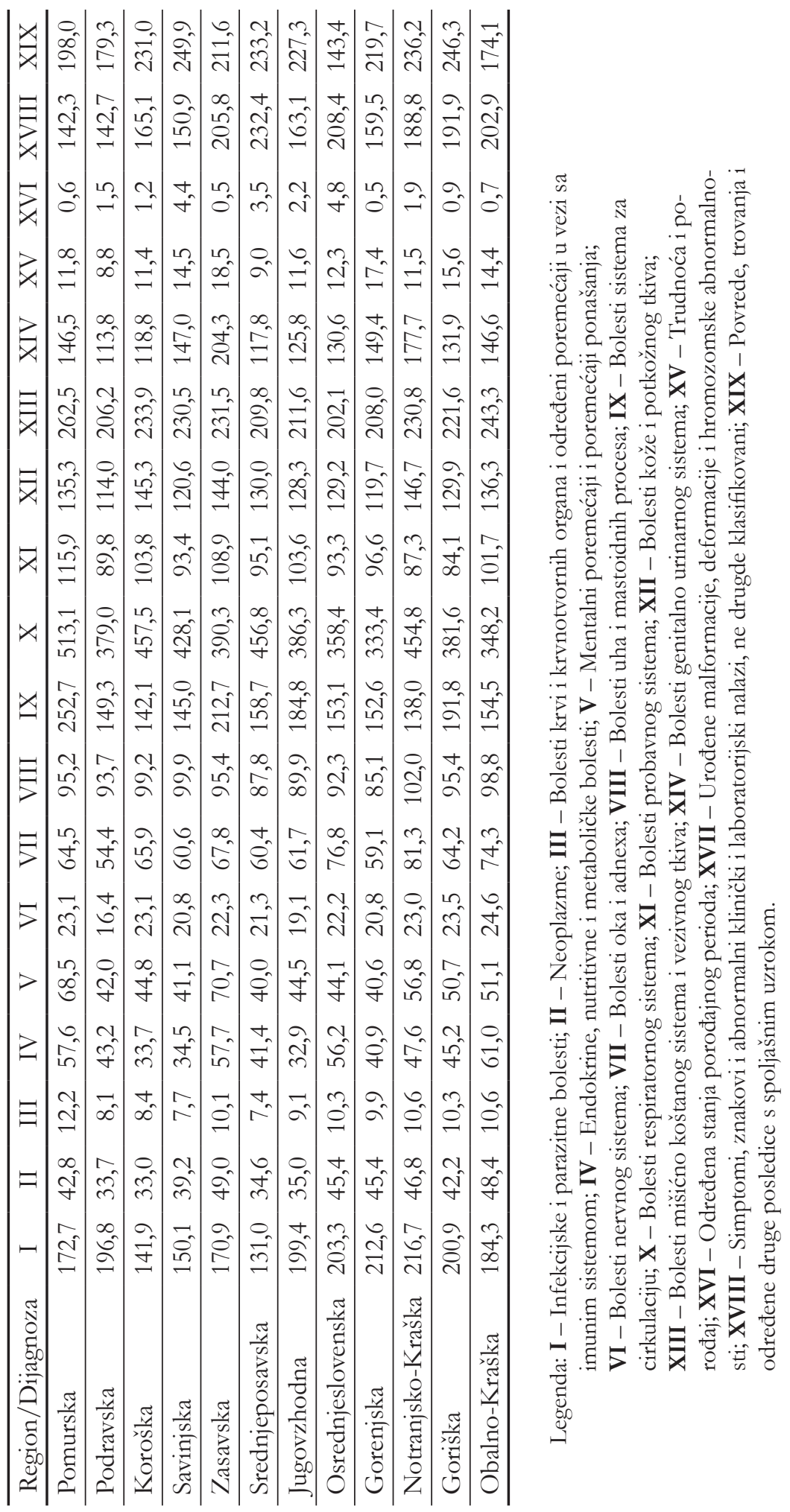


sportskom klubu 18\% nacije ima članstvo. Podravska i Gorenjska regija imaju najveći broj članova sportskog kluba na 1000 stanovnika, a Notranjsko kraška i Jugovzhodna regija najmanji. U poređenju sa rezultatima Sila (2010) i Doupona Topič (2010) (podaci prikupljeni stratifikovanim uzorkom od 1286 osoba), 6\% odraslih Slovena takmiče se u organizovanom sportu, a 19,1\% učestvuje u organizovanom rekreativnom sportu. Drugim riječima: 25,1\% odraslih stanovnika Slovenije trebalo bi biti uključeno u organizovane sportske klubove. Međutim, naši podaci pokazuju manji postotak. Prema olar i saradnici (2010), postoji 87.520 registrovanih sportista u Sloveniji, koji predstavljaju 4,3\% ukupne populacije. Prema istom izvoru, samo 6,4\% (državnih i opštinskih sredstava) sredstava iz budžeta (isključujući ulaganja u objekte) na državnom nivou troši se na rekreativni sport, ostalo je usmjereno na vrhunski sport, sportiste sa posebnim potrebama, školski sport, obrazovne programe i funkcionisanje sportskih organizacija (uglavnom na državnom nivou). Ni jedna osoba ne može se takmičiti na bilo kom nivou ukoliko nije član sportskog kluba (sportski klubovi su uključeni u državna takmičenja i finansiraju ih opštine). Zbog toga se može zaključiti da su $23 \%$ članova sportskih klubova vrhunski sportisti. Ovaj podatak je sličan onome koji je dobio Sila (2010) i Doupona Topič (2010). Prosječno opštinsko ulaganje po osobi u sportskom klubu u Sloveniji je 113,64€ godišnje. U klubovima, većina novca troši se na vrhunske sportiste. Sasvim je jasno da se jako malo $(8,97 €)$ novca troši na prosječne osobe uključene u rekreativni sport. Prosječna mjesečna neto plata po zaposlenom u regijama kreće se između 784,68 € (Pomurska regija) i 938,29 € (Osrednjeslovenska regija). Bednarik, Kolar i Jurak (2010) izvještavaju da prosječno slovensko domaćinstvo potroši $496 €$ godišnje na sport, od čega $375 €$ na opremu, a $121 €$ na sportske usluge. Kako postoje razlike u platama po regijama, može se pretpostaviti da takođe postoje razlike i u sredstvima potrošenim na sportsku opremu i sportske usluge.

\section{TABELA 3}

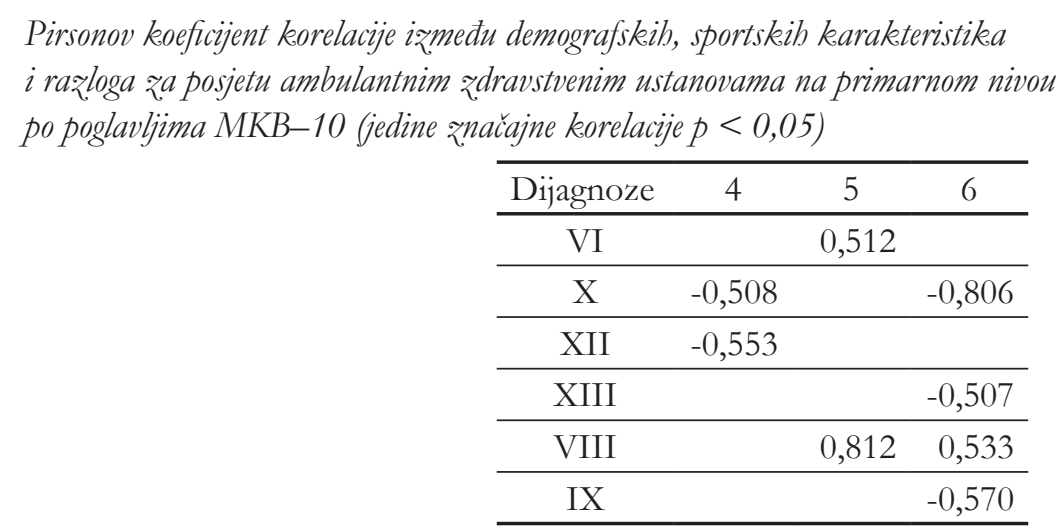

Legenda: 4 - Broj članova klubova / 1.000 stanovnika; 5 - Godišnja javna potrošnja po članu sportskih kluba (EUR); 6 - Prosječna mjesečna neto plata po zaposlenom (EUR); IV - Endokrine, nutritivne i metaboličke bolesti; X - Bolesti respiratornog sistema; XII - Bolesti kože i potkožnog tkiva; XIII - Bolesti mišićno koštanog sistema i vezivnog tkiva; XVIII - Simptomi, znakovi i abnormalni klinički i laboratorijski nalazi, koji nisu klasifikovani; XIX - Povrede, trovanja i određene druge posledice s spoljašnim uzrokom.

Najveći postotak razloga za posjetu ambulantnim zdravstvenim ustanovama na primarnom nivou (Tabela 2) jesu bolesti respiratornog sistema, a odmah za njima bolesti mišićno - koštanog sistema i vezivnog tkiva i ozljede, trovanja i određene druge posljedice s spoljnim uzrokom, a najmanji postotak stvarala su određena stanja perinatalnog perioda.

Korelacija među brojem članova sportskog kluba na 1.000 stanovnika i bolesti respiratornog sistema je negativna, što znači da su regioni sa više članova sportskih klubova imali manje potrebe za liječenjem bolesti respiratornog sistema. Tri glavne dijagnoze kod respiratornog sistema uključuju akutnu infekciju gornjih respiratornih organa, skutni tonzilitis i faringitis. Generalna otpornost na akutne respiratorne infekcije veća je kod onih koji aktivno učestvuju u sportu (Karacabey, 2005; Viru i Smirnova, 1995; Vuori, 2004). Povećanje broja članova sportskih klubova ukazuje na smanjenje pojave bolesti kože i potkožnog tkiva. Tri glavne dijagnoze kod bolesti kože i potkožnog tkiva uključuju dermatitis (L30), urtikariju i neodređeni kontaktni dermatitis. Izgleda da su oni aktivno uključeni u sport više svjesni održavanja higijene kože. 
Javno finansiranje po osobi u sportskom klubu je u pozitivnoj korelaciji sa bolestima nervnog sistema (VI) i sa simptomima, znakovima i abnormalnim kliničkim i laboratorijskim nalazima, ne drugdje klasifikovanim (XVIII). Tri glavne dijagnoze u ovoj grupi uključuju mononeuropatije gornjih udova, epilepsiju i migrene. Tri glavne dijagnoze u grupi XVIII uključuju bolove u abdomenu, glavobolje i visoku temperaturu iz nepoznatih razloga. Izgleda da novac potrošen na sportske klubove i od strane klubova nije korišten efektivno u pravcu pozitivnog učinka na zdravlje. Jedan od razloga takve korelacije moglo bi biti relativno malo ulaganje u rekreativni, a znatno u takmičarski sport. Redistribucija i bolja kontrola opštinskih ulaganja u sportske klubove trebala bi biti jedan od ciljeva opštinskih, sportskih i zdravstvenih vlasti.

Prosječna plata po osobi je od svih demografskih i sportskih varijabli najpovezanija sa zdravstvenim statusom. Što su veća primanja, manja je pojava bolesti respiratornog sistema; bolesti mišićno - koštanog sistema i vezivnog tkiva; i povreda, trovanja i određenih drugih posljedica s spoljnim uzrokom. Čini se da oni koji imaju novca više brinu o svom životu i prihvataju zdrav način življenja. Očito je da oni imaju manje problema sa respiratornim bolestima, jer, vjerovatno, provode više slobodnog vremena u sportskim aktivnostima na otvorenom i zatvorenom prostoru, i imaju veoma visok stepen otpornosti na akutne infekcije. Više sportskih aktivnosti ne izaziva i više problema sa mišićno - skeletnim sistemom i vezivnim tkivom. Naprotiv, dobro pripremljen organizam generalno ima manje problema. Drugim riječima: obrnuta U - kriva je veoma važna za dobru spremnost organizma: prenisko (nema aktivnosti) ili previsoko (vrhunski sport) opterećenje mogu biti štetni po ljudsko tijelo, dok je sve između toga korisno. Dobra forma znači manje povreda izazvanih vanjskim uzrokom. Naši zaključci slažu se sa onima Powell i saradnici. (2006) i Lambert i saradnici (2009). Međutim, postoji pozitivna korelacija sa simptomima, znakovima i abnormalnim kliničkim i laboratorijskim nalazima, ne drugdje klasifikovanim (PXVIII), što bi se moglo dovesti u vezu sa faktorima stresa.

\section{ZAKLJUČAK}

Prema našoj analizi, može se doći do sledećih zaključaka za 2009. godinu:

- veći broj članova sportskih klubova znači manje respiratornih bolesti i bolesti kože i potkožnog tkiva;
- opštinska ulaganja u sportske klubove iz zdravstvene perspektive predstavljaju uzaludno utrošen novac koji nije baziran ni na jedan određen koncept;

- finansijska podrška sportskim klubovima trebala bi biti usmjerena više na rekreativni sport i sport koji promoviše zdravlje nego što je to trenutno;

- visoka primanja su preduslov za smanjenu pojavu bolesti, s obzirom da ljudi višeg socijalno-ekonomskog statusa vode zdraviji život (sportska aktivnost, slobodno vrijeme, bolji stambeni uslovi, ishrana, itd.);

- veći broj članova sportskih klubova važan je za prevenciju bolesti na nacionalnom nivou;

- ako rekreativni sport i sport koji promoviše zdravlje u potpunosti počivaju na konceptu plati - pa - koristi, bez javne podrške, može se očekivati veća pojava bolesti;

- sportski klubovi mogu djelovati kao prirodne apoteke.

\section{LITERATURA}

Almeida, P. W., Gomes-Filho, A., Ferreira, A. J., Rodrigues, C. E., Dias-Peixoto, M. F., Russo, R. C., Teixeira, M. M., ...Pussieldi, G. A. (2009). Swim training suppresses tumor growth in mice. Journal of Applied Physiologyl, 107(1), 261-265.

Bednarik, J., Kolar, E., \& Jurak, G. (2010). Analysis of the sports services market in Slovenia. Kinesiology, 42(2), 142-152.

Bougault, V., Turmel, J., Levesque, B., \& Boulet, L. P. (2009). The respiratory health of swimmers. Sports Medicine, 39(4), 295-312.

Bučar Pajek, M., \& Pajek, J. (2009). Low back pain and possible role of pilates in artistic Gymnastics. Science of Gymnastics Journal, 1(1), 55-61.

Concile of Europe. (1992). The European Sport Charters (No. R (92) 13 REV). Strasbourg.

Doupona Topič, M. (2010) Vpliv socialne stratifikacije na značilnosti športno rekreativne dejavnosti v Sloveniji [Influence of Social Characteristics on Sport Activity in Slovenia]. Sport, 58(1-2), 100-104

Dowdel, T. (2011). Is gymnastics dangerous sport in the Austrlian club cintext. Science of Gymnastics Journal, 3(2), 13-26.

Emery, C., \& Tyreman, H. (2009). Sport participation, sport injury, risk factors and sport safety practices in Calgary and area junior high schools. Paediatrics \& Child Health, 14(7), 439-444. 
Finkelstein, E. A., Chen, H., Prabhu, M., Trogdon, J. G., \& Corso, P. S. (2007). The relationship between obesity and injuries among U.S. adults. American Journal of Health Promotion, 21(5), 460-468.

Gram, B., Christensen, R., Christiansen, C., \& Gram, J. (2010). Effects of nordic walking and exercise in type 2 diabetes mellitus: a randomized controlled trial. Clinical Journal of Sport Medicine, 20(5), 355-361.

Juvonen, R., Bloigu, A., Peitso, A., Silvennoinen-Kassinen, S., Saikku, ...Harju, T. (2008). Training improves physical fitness and decreases CRP also in asthmatic conscripts. Journal of Asthma, 45(3), 237-242.

Kano, K. (1998). Relationship between exercise and bone mineral density among over 5,000 women aged 40 years and above. Journal of Epidemioogyl, $8(1), 28-32$.

Karacabey, K. (2005). Effect of regular exercise on health and disease. Neuroendocrinolgy Letters, 26(5), 617-623.

Kolar, E., Jurak, G., \& Kovač, M. (2010). Analiza nacionalnega programa športa v Republiki Sloveniji 2000 - 2010 [Analyse of Sport National Program in Republic Slovenia 2000 - 2010]. Ljubljana, Slovenia: Fakulteta za šport

Lambert, E. V., da Silva, R., Fatti, L., Patel, D., Kolbe-Alexander, T., Derman, W., ...Gaziano, T. (2009). Fitness-related activities and medical claims related to hospital admissions - South Africa, 2006. Preventing Chronic Disease, 6(4), A120.

Maffulli, N., Longo, U. G., Spiezia, F., \& Denaro, V. (2010). Sports injuries in young athletes: long-term outcome and prevention strategies. The Physician and Sportsmedicine, 38(2), 29-34.

Miculis, C. P., Mascarenhas, L. P., Boguszewski, M. C., \& de Campos, W. (2010) Physical activity in children with type 1 diabetes. Jornal de Pediatria, 86(4), 271-278.

Nichols, D. L., Sanborn, C. F., \& Essery, E. V. (2007). Bone density and young athletic women. Sports Medicine, 37(11), 1001-1014.

de Oliveira, E. P., \& Burini, R. C. (2009). The impact of physical exercise on the gastrointestinal tract. Current Opinion in Clinical Nutrition and $\mathrm{Me}$ tabolic Care, 12(5), 533-538.

Owen, N., Bauman, A., Brown, W., \& Trost, S. (2003). Physical activity and population health outcomes. Journal of Sport sciences and Medicine, 6(3), 368-370.
Powell, L.M., Slater, S., Chaloupka, F. J., \& Harper, D. (2006). Availability of physical activity-related facilities and neighborhood demographic and socioeconomic characteristics: a national study. American Journal of Public Health, 96(9), 1676-1680.

Redelmeier, D. A., \& Greenwald, J. A. (2007). Competing risks of mortality with marathons: retrospective analysis. British Medical Journal, 22;335(7633), 1275-1277.

Rogers, R. S., \& Hinton, P. S. (2010). Bone loading during young adulthood predicts bone mineral density in physically active, middle-aged men. The Physician and Sportsmedicine, 38(2), 146-155.

Sila, B. (2010). Športno rekreativna dejavnost Slovencev 2008 [Sports and recreational activities of Slovenes 2008]. Sport, 58(1-2), 89-93.

Snyder, A. R., Martinez, J. C., Bay, R. C., Parsons, J. T., Sauers, E. L., \& Valovich McLeod, T. C. (2010). Health-related quality of life differs between adolescent athletes and adolescent nonathletes. Journal of Sport Rehabilitation, 19(3), 237-248.

Sattelmair, J. R., Kurth, T., Buring, J. E., \& Lee, I. M. (2010). Physical activity and risk of stroke in women. Stroke, 41(6), 1243-1250.

Stammes, R., \& Spijker, J. (2009). Physical training to treat depression. Tijdschrift voor psychiatrie, 51(11), 821-830.

Tanaka, H. (2009). Swimming exercise: impact of aquatic exercise on cardiovascular health. Sports Medicine, 39(5), 377-387.

Viru, A., \& Smirnova, T. (1995). Health promotion and exercise training. Sports Medicine, 19(2), 123-136.

Vuori, I.(2004). Physical inactivity is a cause and physical activity is a remedy for major public helath problems. Kinesiology, 36(2), 123-153.

Weisgerber, M., Danduran, M., Meurer, J., Hartmann, K., Berger, S., \& Flores, G. (2009). Evaluation of Cooper 12-minute walk/run test as a marker of cardiorespiratory fitness in young urban children with persistent asthma. Clinical Journal of Sport Medicine, 19(4), 300-305.

Zheng, H., Ehrlich, F., \& Amin, J. (2010). Economic evaluation of the direct healthcare cost savings resulting from the use of walking interventions to prevent coronary heart disease in Australia. International Journal of Health Care Finance and Economics, 10(2), 187-201.

World Helth Organization. (1986). Ottawa Charter for Health Promotion First International Conference on 
Health Promotion (WHO/HPR/HEP/95.1). Ot-

tawa.

Primljeno: 9 novembra 2011. godine Izmjene primljene: 16. novembar 2011. godine

Odobreno: 19. novembar, 2011. godine

Correspodence to: Prof. dr Ivan Čuk Fakultet za šport Gortanova 22 1000 Ljubljana Slovenija e-mail: ivan.cuk@fsp.uni-lj.si Telefon: 00386152707700 Fax: 0038615207740 